\title{
Properties of Nicotinamide Adenine Dinucleotide Phosphate-Dependent Formate Dehydrogenase from Clostridium thermoaceticum
}

\author{
LAN-FUN LI, ${ }^{1}$ LARS LJUNGDAHL, AND HARLAND G. WOOD \\ Department of Biochemistry, Western Reserve University, School of Medicine, Cleveland, Ohio
}

Received for publication 9 May 1966

\begin{abstract}
LI, LAN-Fun (Western Reserve University School of Medicine, Cleveland, Ohio), Lars LJungdahl, and Harland G. Wood. Properties of nicotinamide adenine dinucleotide phosphate-dependent formate dehydrogenase from Clostridium thermoaceticum. J. Bacteriol. 92: 405-412. 1966.-A nicotinamide adenine dinucleotide phosphate (NADP)-dependent formate dehydrogenase has been isolated from $C$. thermoaceticum. The enzyme is very sensitive to oxygen and requires sulfhydryl compounds for activity. The apparent $K_{\mathrm{m}}$ at $50 \mathrm{C}$ and $p \mathrm{H} 7.0$ for NADP is $5.9 \times$ $10^{-5} \mathrm{M}$ and for formate, $2.2 \times 10^{-4} \mathrm{M}$. The enzyme is most active at about $60 \mathrm{C}$ and at $p \mathrm{H}$ values between 7.0 and 9.0. The enzyme catalyzes an exchange between $\mathrm{C}^{14} \mathrm{O}_{2}$ and formate, which requires NADP, but net synthesis of formate from $\mathrm{CO}_{2}$ and reduced nicotinamide adenine dinucleotide phosphate could not be demonstrated. The reaction does not involve ferredoxin.
\end{abstract}

Clostridium thermoaceticum produces 3 moles of acetate from glucose, 1 of which is formed by a total synthesis of acetate from carbon dioxide $(2,21)$. A number of observations indicate that formate is an intermediate in the reduction of carbon dioxide to the methyl group of acetate. Lentz and Wood (9) demonstrated that $\mathrm{C}^{14}$ formate is preferentially incorporated into the methyl group of acetate, and that whole cells catalyze a rapid exchange reaction between $\mathrm{C}^{14} \mathrm{O}_{2}$ and formate. With cell suspensions and $\mathrm{C}^{14} \mathrm{O}_{2}$, Ljungdahl and Wood (11) found that in $5 \mathrm{sec}$ the formate had a higher specific activity than the methyl group of acetate. Furthermore Ljungdahl, Irion, and Wood (10) demonstrated with cell-free extracts that addition of formate decreased the incorporation of $\mathrm{C}^{14} \mathrm{O}_{2}$ into the methyl group of acetate. The present paper describes some properties of a nicotinamide adenine dinucleotide phosphate (NADP)-dependent formate dehydrogenase in $C$. thermoaceticum. A preliminary report of this work has been published (L. Ljungdahl and H. G. Wood, Bacteriol. Proc. p. 109, 1963).

\section{Materials ANd Methods}

Growth of $C$. thermoaceticum and preparation of extract. C. thermoaceticum was grown for 4 days at $55 \mathrm{C}$

\footnotetext{
${ }^{1}$ Present address: Department of Biochemistry, School of Medicine, St. Louis University, St. Louis, Mo.
}

under $\mathrm{CO}_{2}$ in the medium described by Lentz and Wood (9), to which $45 \mathrm{ml}$ of boiled and filtered tomato juice was added per liter. The cells were harvested, and an extract was prepared with a French press (American Instrument Co., Silver Spring, Md.), as described by Ljungdahl et al. (10). The extract was centrifuged at $35,000 \times g$ for $40 \mathrm{~min}$, and the clear, dark-brown supernatant fluid contained the formate dehydrogenase activity. The enzyme was stored in ice under nitrogen or argon.

Exchange between $\mathrm{C}^{14} \mathrm{O}_{2}$ and formate. For a study of cofactor requirements of the exchange reaction between $\mathrm{C}^{14} \mathrm{O}_{2}$ and formate, the crude extract was treated as follows: $7.8 \mathrm{~g}$ of ammonium sulfate was added to $12 \mathrm{ml}$ of extract. After $20 \mathrm{~min}$ at $0 \mathrm{C}$, the precipitate was obtained by centrifugation at $17,000 \times$ $g$ for $20 \mathrm{~min}$. It was dissolved in $10 \mathrm{ml}$ of $0.1 \mathrm{M}$ potassium phosphate buffer $(p H$ 7.0) containing $0.02 \mathrm{M}$ mercaptoethanol and was dialyzed for $4 \mathrm{hr}$ at $4 \mathrm{C}$ against $500 \mathrm{ml}$ of the same buffer. The buffer was changed once after $2 \mathrm{hr}$. Incubations with this enzyme were carried out anaerobically under $\mathrm{N}_{2}$ at $60 \mathrm{C}$. The reactions were stopped by addition of $4 \mathrm{~N}$ sulfuric acid to a $p \mathrm{H}$ below 2 . Radioactivity of the evolved $\mathrm{CO}_{2}$ was determined after trapping it as barium carbonate. Formate was separated by steam distillation and converted to $\mathrm{CO}_{2}$ by oxidation with mercuric dichloride (14) for assay of $\mathrm{C}^{14}$ as barium carbonate.

Spectrophotometric assay of formate dehydrogenase. The crude extract from $C$. thermoaceticum catalyzes a reduction of NADP in the presence of formate. The assay mixture contained $(\mu \mathrm{moles} / \mathrm{ml})$ : potassium phosphate buffer ( $p \mathbf{H} 7.0), 100$; NADP, 1 ; cysteine, 40 ; formate, 20; and $B_{12}$ (cyanocobalamin), 0.35 . 
All solutions were made up with water previously boiled to eliminate dissolved air and were kept anaerobic under argon. The cuvettes were closed with rubber stoppers and were gassed with argon via syringe needles. Transfer of reagents and enzymes from stock solutions to the cuvettes was made by use of syringes. The reaction mixture was preincubated under argon at $50 \mathrm{C}$ for $5 \mathrm{~min}$ before the reaction was started by the addition of the enzyme. The production of reduced nicotinamide adenine dinucleotide phosphate $\left(\mathrm{NADPH}_{2}\right)$ was followed at $340 \mathrm{~m} \mu$ by use of a Beckman spectrophotometer with a Gilford automatic recorder (Gilford Instrument Laboratories, Oberlin, Ohio). The enzyme is strongly inhibited by oxygen. In spite of the above precautions, some oxygen is still present, which probably is the cause of a lag period observed at the start of the enzymatic reaction. The oxygen is slowly removed by cysteine, and this reaction is accelerated in the presence of $B_{12}$ (13). After removal of the oxygen, the enzymatic reaction reaches maximal rate, which is linear for several minutes. This rate is the basis for calculation of the enzymatic activity. One unit of enzyme is defined as the amount that catalyzes the formation of $1 \mu$ mole of $\mathrm{NADPH}_{2}$ per minute at $p \mathrm{H} 7.0$ and $50 \mathrm{C}$, and specific activity is expressed as units per milligram of protein. The readings were corrected for the control values obtained in the absence of formate.

Preparation of ferredoxin and a pyruvate clastic enzyme free from ferredoxin. C. pasteurianum W-5 (American Type Culture Collection no. 6013) was grown for $36 \mathrm{hr}$ at $37 \mathrm{C}$, as described by Carnahan and Castle (5), and $55 \mathrm{~g}$ of wet cells was obtained from 36 liters of medium. The cells were washed with $500 \mathrm{ml}$ of $0.05 \mathrm{M}$ potassium phosphate buffer $(p \mathrm{H} 6.5)$ and were resuspended in $150 \mathrm{ml}$ of water. The suspension was passed through a French press and, after centrifugation at $35,000 \times g$ for $30 \mathrm{~min}$, the supernatant fluid was applied to a diethylaminoethyl (DEAE) cellulose column, 3.5 by $8 \mathrm{~cm}$ (12). The effluent from the column was lyophilized immediately, and the dry powder, stored at $-20 \mathrm{C}$, was used as a clastic system free from ferredoxin for assay of ferredoxin according to Buchanan, Lovenberg, and Rabinowitz (4). The DEAE column was washed with $500 \mathrm{ml}$ of water and $500 \mathrm{ml}$ of $0.05 \mathrm{M}$ potassium phosphate $(\mathrm{pH} 6.5)$, and the ferredoxin was eluted with $110 \mathrm{ml}$ of $0.15 \mathrm{M}$ tris(hydroxymethyl)aminomethane (Tris)- $\mathrm{HCl} \quad(p \mathrm{H}$ 7.3) in $0.67 \mathrm{M} \mathrm{NaCl}$. The ferredoxin fraction was dialyzed for $12 \mathrm{hr}$ against 6 liters of water. The dialyzed ferredoxin catalyzed the formation of 1.05 $\mu$ moles of acetyl phosphate per $10 \mathrm{~min}$ per $\mathrm{mg}$ of protein in the assay described by Buchanan et al. (4).

Partial purification of formate dehydrogenase from C. thermoaceticum. The purification of formate dehydrogenase from $C$. thermoaceticum is summarized in Table 1. Operations were performed at $4 \mathrm{C}$ unless stated otherwise.

Step I: First ammonium sulfate fractionation. Solid ammonium sulfate $(135 \mathrm{~g})$ was added to $504 \mathrm{ml}$ of cell-free extract obtained from $185 \mathrm{~g}$ of wet cells. The precipitate containing $95 \%$ of the formate dehydrogenase was recovered by centrifugation for $\mathbf{3 0}$ min at $35,000 \times g$. To the supernatant fluid, ammonium sulfate $(28.5 \mathrm{~g} / 100 \mathrm{ml})$ was added to obtain about $80 \%$ saturation. The precipitate obtained contains enzymes which catalyze the exchange between $\mathrm{C}^{14} \mathrm{O}_{2}$ and pyruvate (Ljungdahl and Wood, Bacteriol. Proc., p. 109, 1963).

Step II: Heat treatment and second ammonium sulfate fractionation. The 0 to $40 \%$ ammonium sulfate precipitate from step I was dissolved in $500 \mathrm{ml}$ of

TABLE 1. Purification of formate dehydrogenase from Clostridium thermoaceticum

\begin{tabular}{|c|c|c|c|c|c|}
\hline Step & Fraction & Total protein & $\begin{array}{l}\text { Specific } \\
\text { activity }^{a}\end{array}$ & Units $^{b}$ & Recovery \\
\hline \multirow{4}{*}{ I } & & $g$ & & & $\%$ \\
\hline & Crude $\operatorname{extract}(\ldots \ldots \ldots \ldots \ldots \ldots \ldots \ldots$ & 13.61 & 0.0024 & 32.7 & 100 \\
\hline & $\left(\mathrm{NH}_{4}\right)_{2} \mathrm{SO}_{4}$ precipitate, $40 \%$ saturation.. & 6.10 & 0.0053 & 32.3 & 98.7 \\
\hline & $\left(\mathrm{NH}_{4}\right)_{2} \mathrm{SO}_{4}$ precipitate, $80 \%$ saturation. & 5.35 & 0.0002 & 1.0 & 3.3 \\
\hline \multirow{6}{*}{ II } & 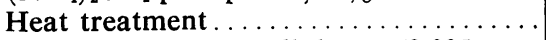 & 3.63 & 0.0096 & 34.8 & 106.2 \\
\hline & Eluate 1 , DEAE cellulose, $(0.005 \mathrm{M}$ & 0.31 & 0.0006 & 0.2 & 0.5 \\
\hline & $\begin{array}{l}\text { Eluate } 2, \text { DEAE cellulose, }(0.05 \mathrm{M} \\
\text { buffer, } p \mathrm{H} 7.5) \ldots \ldots \ldots \ldots\end{array}$ & 0.15 & 0.0000 & 0.0 & 0.0 \\
\hline & $\begin{array}{l}\text { Eluate } 3, \text { DEAE cellulose, }(0.1 \mathrm{~m} \text { buffer, } \\
p \mathrm{H} 7.5) \ldots \ldots \ldots \ldots \ldots \ldots \ldots \ldots \ldots\end{array}$ & 0.17 & 0.0007 & 0.1 & 0.4 \\
\hline & $\begin{array}{l}\text { Eluate } 4, \text { DEAE cellulose, }(0.2 \mathrm{~m} \text { buffer } \\
\quad p \mathrm{H} \text { 7.0 }\end{array}$ & 0.76 & 0.0116 & 8.8 & 27.0 \\
\hline & $\begin{array}{l}\text { Eluate 5, DEAE cellulose, }(0.2 \mathrm{~m} \text { buffer, } \\
\quad p \mathrm{H} \text { 6.5) } \ldots \ldots \ldots \ldots \ldots \ldots \ldots \ldots \ldots\end{array}$ & 0.37 & 0.0008 & 0.3 & 0.9 \\
\hline \multirow[t]{2}{*}{ IV } & $\begin{array}{l}\text { Negative adsorption with Amberlite } \\
\text { CG-50 } \ldots \ldots \ldots \ldots \ldots \ldots \ldots \ldots \ldots\end{array}$ & 0.41 & 0.0139 & 5.7 & 17.3 \\
\hline & $\begin{array}{c}\text { Negative adsorption with cellulose } \\
\text { phosphate } \ldots \ldots \ldots \ldots \ldots \ldots \ldots \ldots\end{array}$ & 0.33 & 0.0177 & 5.8 & 17.8 \\
\hline
\end{tabular}

${ }^{a}$ Expressed as units per milligram of protein.

${ }^{b}$ Micromoles of $\mathrm{NADPH}_{2}$ per minute. 
distilled water from which air had been removed by boiling, and the mixture was flushed with $\mathrm{N}_{2}$. The solution under $\mathrm{N}_{2}$ atmosphere was heated to 61 to $63 \mathrm{C}$ in a water bath and was kept at this temperature for $5 \mathrm{~min}$ and then cooled immediately in an ice-water bath. Ammonium sulfate $(14.4 \mathrm{~g} / 100 \mathrm{ml})$ was added to obtain $25 \%$ saturation, and the precipitate was removed by centrifugation.

Step III: Adsorption on DEAE cellulose and batch elution. DEAE cellulose (type 40, capacity $0.9 \mathrm{meq}$ per g, Brown Co., Berlin, N.H.) was washed with $0.2 \mathrm{~N} \mathrm{NaOH}$, water, $0.1 \mathrm{~N} \mathrm{HCl}$, and water, and was equilibrated with $0.005 \mathrm{M}$ sodium phosphate $(\mathrm{pH} 7.5)$. The supernatant solution from step II was dialyzed against 6 liters of $0.005 \mathrm{M}$ sodium phosphate buffer $(p \mathrm{H} \mathrm{7.5)}$ for $5 \mathrm{hr}$ with a change of buffer at $2.5 \mathrm{hr}$. An equal volume of gravity-packed DEAE cellulose was added to the dialyzed solution, and the mixture was stirred under a $\mathrm{N}_{2}$ atmosphere for $45 \mathrm{~min}$. The DEAE-cellulose was separated from the solution by filtration through a Büchner funnel with Whatman no. 4 filter paper, and was resuspended in $800 \mathrm{ml}$ of $0.05 \mathrm{M}$ sodium phosphate buffer $(p \mathrm{H} \mathrm{7.5)}$. This procedure was repeated with $800 \mathrm{ml}$ of $0.1 \mathrm{M}$ buffer at $p \mathrm{H} 7.5$, and $0.2 \mathrm{M}$ phosphate buffer at $p \mathrm{H} 7.0$ and 6.5. Only the eluate with $0.2 \mathrm{M}$ buffer at $p \mathrm{H} 7.0$ (eluate 4) contained substantial formate dehydrogenase activity. Unfortunately, much activity is lost in this step, probably because of inactivation of the enzyme by oxygen.

Step IV: Negative adsorption with Amberlite CG-50 and cellulose phosphate. Amberlite CG-50 (100 to 200 mesh, Mallinckrodt Chemical Works, St. Louis, Mo.) was washed with $\mathrm{NaOH}$, acetone, and $\mathrm{HCl}$, as described by Hirs (8), and was equilibrated with $0.2 \mathrm{M}$ sodium phosphate buffer $(p \mathrm{H}$ 6.5). The eluate 4 from step III was dialyzed against 6 liters of the same buffer, and then $300 \mathrm{ml}$ of the settled Amberlite CG-50 was added to it. The mixture was stirred for $1 \mathrm{hr}$. The resin was removed by filtration, and $200 \mathrm{ml}$ of gravity-packed cellulose phosphate (Brown Co., Berlin, N.H.) was added to the filtrate containing the formate dehydrogenase. The cellulose phosphate had been washed as described for the DEAE cellulose and equilibrated with $0.2 \mathrm{M}$ sodium phosphate $(p \mathrm{H} 6.5)$. After being stirred for $30 \mathrm{~min}$, the cellulose-phosphate was removed by filtration. The filtrate containing the formate dehydrogenase was used for investigation of properties of the enzyme.

Protein determination. Protein was determined by the biuret method (7) or by the spectrophotometer method (19).

\section{RESULTS}

Exchange of $\mathrm{C}^{14}$ between $\mathrm{CO}_{2}$ and formate. Figure 1 shows that the exchange of $\mathrm{C}^{14} \mathrm{O}_{2}$ into formate or of formate- $\mathrm{C}^{14}$ into $\mathrm{CO}_{2}$ requires NADP. A very small exchange occurred in absence of the nucleotide, and addition of nicotinamide adenine dinucleotide (NAD) failed to stimulate the reaction. There was a lag period in all the exchange reactions.

Formate-dependent reduction of NADP by

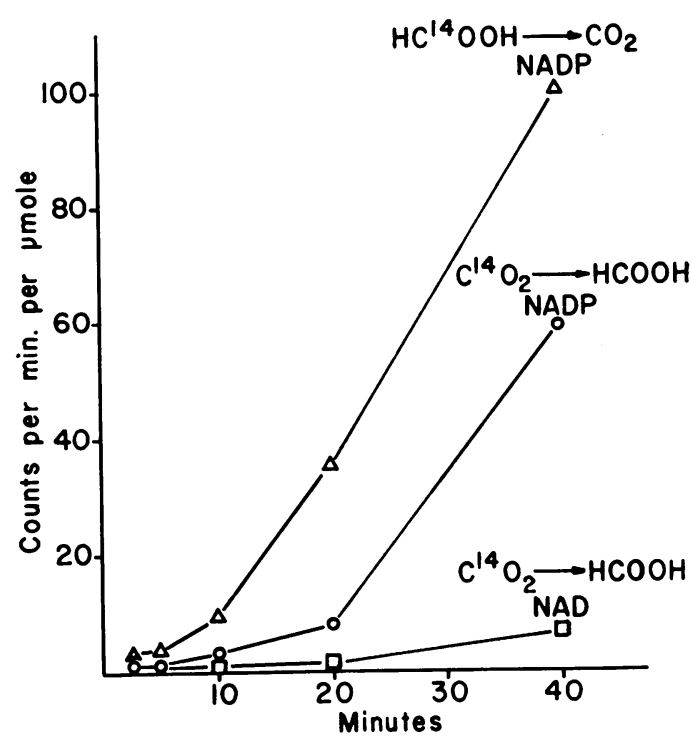

FIG. 1. Effect of nicotinamide adenine dinucleotide (NAD) and nicotinamide adenine dinucleotide phosphate $(N A D P)$ on the exchange of $\mathrm{CO}_{2}$ and formate as catalyzed by the enzyme from Clostridium thermoaceticum. Reaction mixture $(10 \mathrm{ml})$ : enzyme, $10 \mathrm{mg}$ (see Materials and Methods); potassium phosphate buffer (pH 7.0), 500 umoles; 2-mercaptoethanol, 100 umoles; and additions as indicated below. $\mathrm{HC}^{14} \mathrm{OOH} \rightleftarrows$ $\mathrm{CO}_{2}$ exchange $(\triangle): C^{14}$-sodium formate, 100 umoles $(4,000$ counts per min per umole $) ; \mathrm{KHCO}_{3}, 1,000$ umoles; $\mathrm{NADP}, 1$ umole. $\mathrm{C}^{14} \mathrm{O}_{2} \rightleftarrows \mathrm{HCOOH}$ exchange (O): $\mathrm{KHC}^{14} \mathrm{O}_{3}, 100$ umoles $(4,000$ counts per min per umole); sodium formate, 1,000 umoles; NADP, 1 $\mu$ mole. $\mathrm{C}^{14} \mathrm{O}_{2} \rightleftarrows \mathrm{HCOOH}$ exchange ( $\left.\square\right): \mathrm{KHC}^{14} \mathrm{O}_{3}$, 100 mmoles (4,000 counts per min per umole); sodium formate, 1,000 umoles; and NAD, 1 umole or none. Gas phase, $\mathrm{N}_{2}$; temperature, $60 \mathrm{C}$. Samples were withdrawn after $2.5,5,10,20$, and $40 \mathrm{~min}$ for assay of $\mathrm{C}^{14}$ incorporated into $\mathrm{CO}_{2}$ or formate.

crude extract of $C$. thermoaceticum. The oxidation of formate can be measured spectrophotometrically at $340 \mathrm{~m} \mu$, as shown in Fig. 2. The rate of the reduction was slow at first and then reaches a constant rate which was proportional to the amount of enzyme (Fig. 3).

Properties of partially purified formate dehydrogenase from $C$. thermoaceticum. Properties of the formate dehydrogenase were investigated with enzyme from step IV of the purification.

Effect of $p H$. The influence of $p \mathrm{H}$ on the reaction was studied with the following buffers: potassium phosphate, from $p \mathrm{H} 5.0$ to 8.0; Tris$\mathrm{HCl}, p \mathrm{H} 7.1$ to 9.1 ; and glycine- $\mathrm{NaOH}$, from $p \mathrm{H} 9.0$ to 10.0 . The concentration of the buffers was $0.1 \mathrm{M}$. The enzyme was most active between $p \mathrm{H} 7$ and 9, and had only very little activity below $p H$ 6.0. NADP is unstable at alkaline 


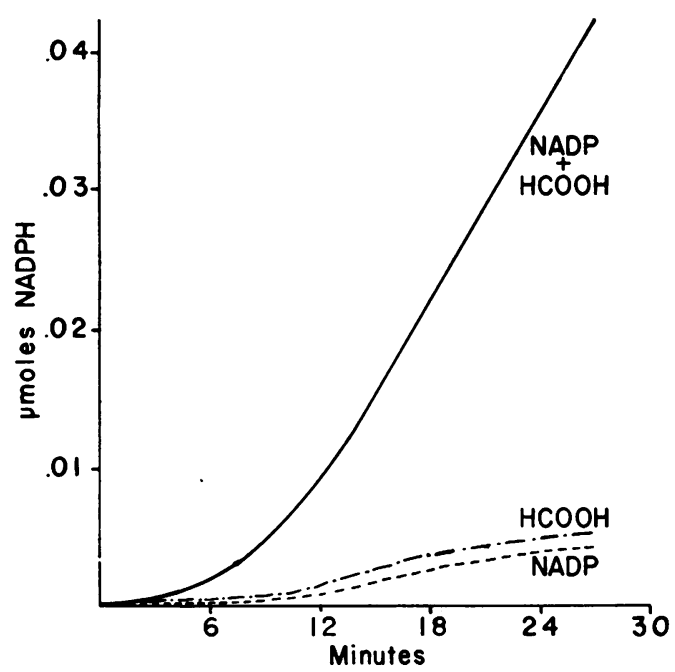

Fig. 2. Spectrophotometric assay of formate dehydrogenase in a crude extract of Clostridium thermoaceticum. The conditions were $50 \mathrm{C}$ under argon, with potassium phosphate buffer ( $p H$ 7.0), 100 umoles; NADP, 1 umole; cysteine, 40 umoles; formate, 20 umoles; $B_{12}, 0.35$ umoles; and $0.1 \mathrm{ml}$ of crude extract (2.5 $\mathrm{mg}$ of protein) in a total volume of $1 \mathrm{ml}$. The reaction was started by the addition of the enzyme. Both $N A D P$ and $H C O O H$ were required for the reaction, although a small increase at $340 \mathrm{m \mu}$ was observed with $H C O O H$ or NADP alone, probably due to endogenous substrate.

$p \mathrm{H}$, particularly at high temperatures; therefore, the assay was usually done at $p \mathrm{H} 7.0$ (6).

Effect of temperature. C. thermoaceticum grew optimally around $60 \mathrm{C}$, and the enzyme also had optimal activity around 60 to $65 \mathrm{C}$, as shown in Fig. 4. Below $40 \mathrm{C}$ the enzyme had very low activity, and above $65 \mathrm{C}$ it was rapidly inactivated.

$K_{\mathrm{m}}$ values. The determination of $K_{\mathrm{m}}$ for NADP is shown in Fig. 5 and for formate in Fig. 6. The apparent $K_{\mathrm{m}}$ for NADP at $p \mathrm{H} 7.0$ and $50 \mathrm{C}$ was $5.9 \times 10^{-5} \mathrm{M}$ and for formate, $2.2 \times 10^{-4} \mathrm{M}$.

Stability of formate dehydrogenase. The enzymatic activity was rapidly lost when formate dehydrogenase was stored at $4 \mathrm{C}$ or frozen (Table 2). However, most of the activity remained after 5 days at $-10 \mathrm{C}$ when the enzyme was stored as ammonium sulfate precipitate.

Requirement for the formate dehydrogenase reactions. Sulfhydryl compounds were required in addition to NADP for activity. Enzyme solutions, when filtered through active charcoal (Norit A), did not lose activity, and this treatment actually resulted in an increase of the specific activity which in one case was 0.0055 to 0.0068. Addition of boiled cell-free extract did not enhance the activity. No metal or other coenzyme requirement was found for the reaction.

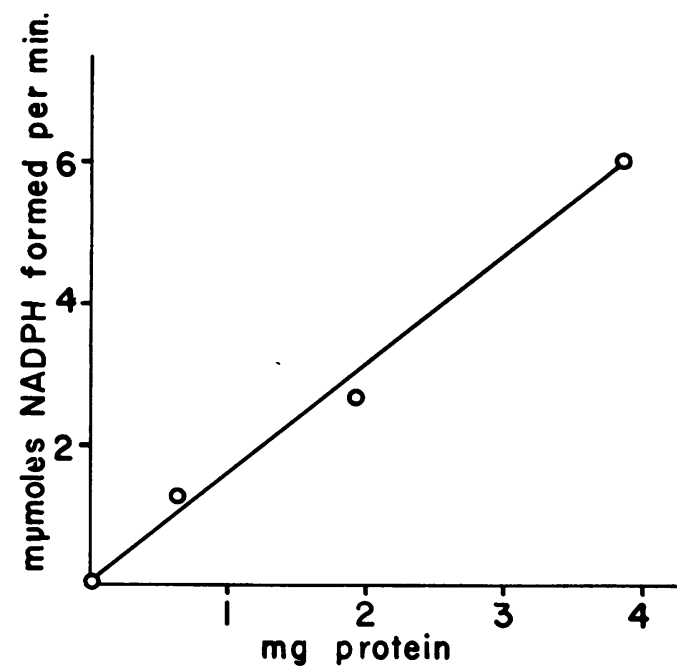

FIG. 3. Proportionality of enzyme and reduction of NADP by formate. The reactions were carried out as described in Fig. 2, and the values are those obtained after the rate became constant.

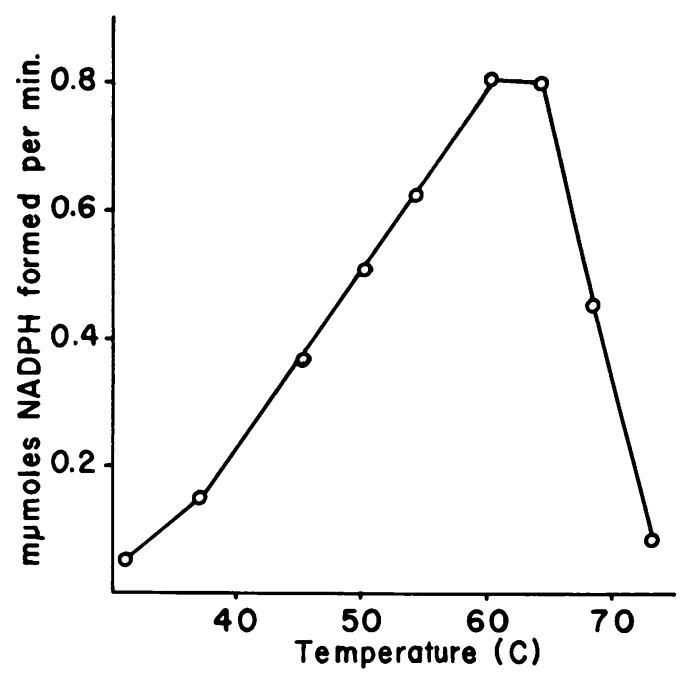

FiG. 4. Effect of temperature on formate dehydrogenase activity. Conditions as described in Fig. 2 with $0.163 \mathrm{mg}$ of purified enzyme.

Effect of oxygen and cyanocobalamin on formate dehydrogenase. The presence of oxygen in the assay mixture completely abolished the enzymatic activity. Small amounts of oxygen were slowly removed by sulfhydryl compounds, and when the oxygen concentration was low the reduction of NADP began and the rate increased as the concentration of oxygen decreased. Table 3 shows that the presence of oxygen increased the lag period and decreased the rate of the reaction. All 


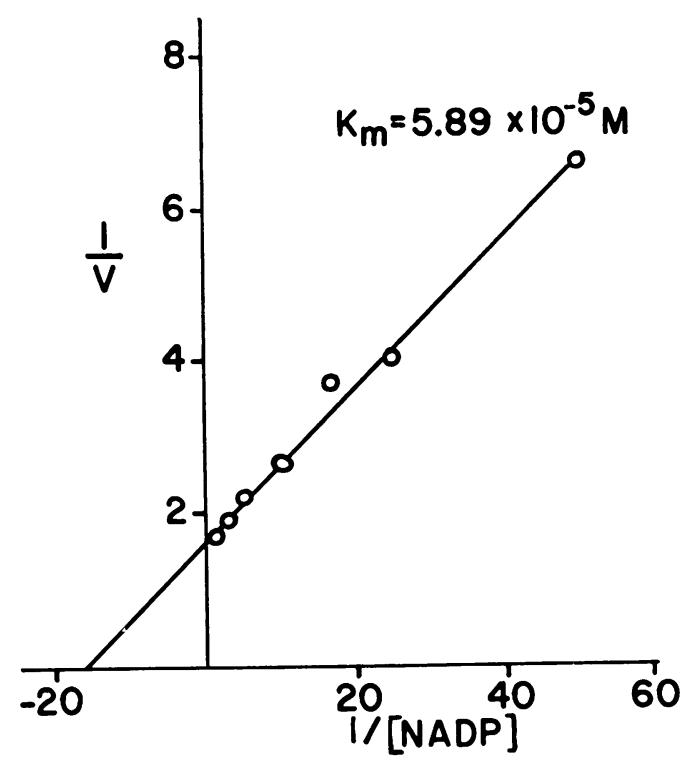

FIG. 5. Determination of apparent $K_{m}$ of $N A D P$ for formate dehydrogenase. Conditions as described in Fig. 2 with $0.085 \mathrm{mg}$ of purified enzyme. $V$ is in millimicromoles of $\mathrm{NADPH}_{2}$ formed per minute, and the concentration of NADP is millimolar.

cuvettes were gassed with argon to remove oxygen, but in spite of this some oxygen $(0.113$ $\mu \mathrm{mole} / \mathrm{ml})$ was left at zero-time. The oxygen was determined polarographically with an oxygen electrode. After $90 \mathrm{~min}$ of incubation without 2-mercaptoethanol, the oxygen decreased to $0.083 \mu \mathrm{mole} / \mathrm{ml}$, but no NADP reduction was observed. Addition of 2-mercaptoethanol in increasing amounts decreased the oxygen content in the reaction mixture, shortened the lag period, and increased the rate of the reduction of NADP. When $0.35 \mu$ mole of $B_{12}$ was added to a cuvette containing $6 \mu$ moles of 2-mercaptoethanol, the lag period was shortened from 30 to 7 min, but the maximal rate of NADP reduction was about the same (Table 3 ).

The inhibiting effect of oxygen on formate dehydrogenase is also illustrated in Fig. 7. Air, corresponding to $1 \mu$ mole of oxygen, was injected into reactions performed as described for the assay of formate dehydrogenase. On addition of air, the reduction of NADP stopped and a decrease in $\mathrm{NADPH}_{2}$ concentration was observed. This decrease may indicate the presence of $\mathrm{NADPH}_{2}$ oxidase. In the sample containing $B_{12}$, the reduction of NADP resumed after $1 \mathrm{~min}$ and at about the same rate as before the injection of air. In the sample without $\mathrm{B}_{12}$, the NADP reduction resumed at a lower rate.

Ferredoxin and formate dehydrogenase in $C$. thermoaceticum. Brill, Wolin, and Wolfe (3) re-

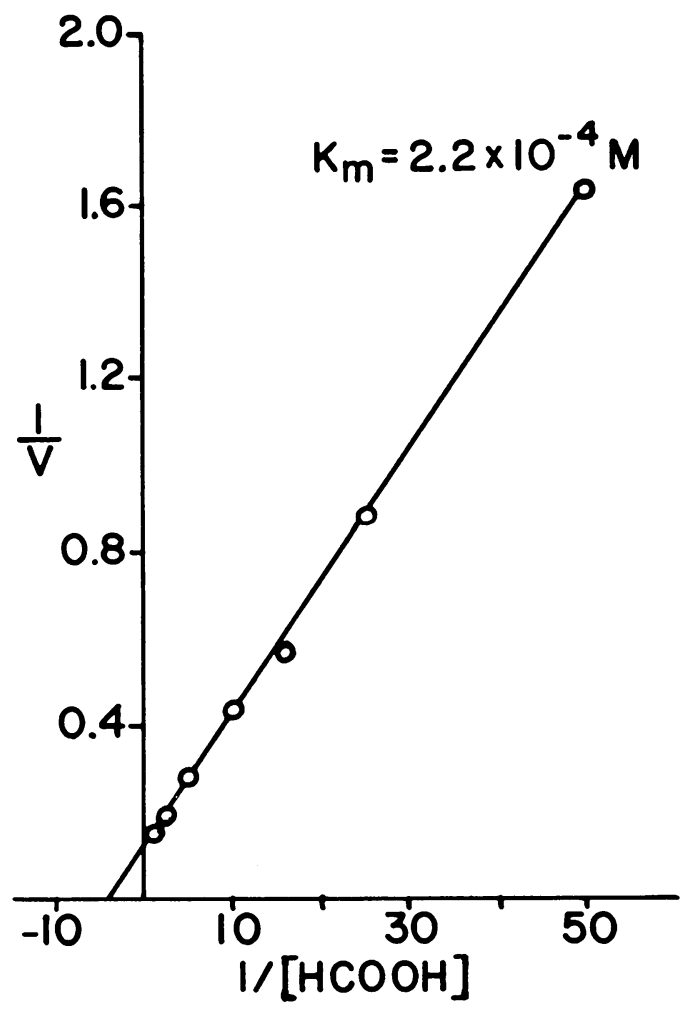

Fig. 6. Determination of apparent $K_{m}$ of formate for formate dehydrogenase. Conditions as described in Fig. 2 with $0.300 \mathrm{mg}$ of purified enzyme. $V$ is millimicromoles of $\mathrm{NADPH}_{2}$ formed per minute, and the concentration of formate is millimolar.

ported that the reduction of NAD by formate in Methanobacterium omelianskii is ferredoxin-dependent. Valentine and Wolfe (18) found that ferredoxin does not couple with formate dehydrogenase from C. acidiurici or from Desulfovibrio desulfuricans. However, in later experiments ferredoxin was found to couple with formate dehydrogenase in $C$. acidiurici (17). Therefore, the effect of ferredoxin on formate dehydrogenase from $C$. thermoaceticum was investigated. A crude extract from $C$. thermoaceticum $(65 \mathrm{ml}$ containing $1.22 \mathrm{~g}$ of protein) was passed through a DEAE column ( 4 by $5 \mathrm{~cm}$ ) prepared as described by Mortenson et al. (12) for isolation of ferredoxin. The fraction passing directly through the column contained the formate dehydrogenase activity (specific activity, 0.0027). The dehydrogenase was precipitated by addition of ammonium sulfate to $40 \%$ saturation. The precipitate was dissolved in $0.1 \mathrm{M}$ potassium phosphate buffer $(p \mathrm{H} 7.0)$ and contained formate dehydrogenase (specific activity, 0.0076). The fraction which should have contained ferredoxin was obtained by elution with $1 \mathrm{M}$ potassium phosphate $(p H \mathbf{H} 6.5)$. It was 
TABLE 2. Stability of purified formate dehydrogenase from Clostridium thermoaceticum at low temperature ${ }^{a}$

\begin{tabular}{c|l|c|c}
\hline \multirow{2}{*}{ Expt } & \multicolumn{1}{|c|}{ Storage } & $\begin{array}{l}\text { Specific } \\
\text { activity }\end{array}$ & $\begin{array}{c}\text { Per } \\
\text { cent }\end{array}$ \\
\cline { 2 - 3 } 1 (Enzyme in & Freshly prepared & 0.018 & 100 \\
solution) & 2 days at 4 C & 0.008 & 44 \\
& 4 days at 4 C & 0.006 & 30 \\
& 28 days at 4 C & 0.00 & 0.0 \\
& 12 days at -10 C & 0.003 & 19 \\
& 28 days at -10 C & 0.00 & 0.0 \\
$2\left(\mathrm{NH}_{4}\right)_{2} \mathrm{SO}_{4}$ & Freshly prepared & 0.023 & 100 \\
precipitate) & 5 days at -10 C & 0.022 & 95 \\
\hline
\end{tabular}

${ }^{a}$ The reactions were carried out as described in Fig. 2. In experiment 1 , the enzyme concentration was $0.82 \mathrm{mg} / \mathrm{ml}$ in $0.2 \mathrm{M}$ phosphate buffer $(p \mathrm{H} 6.5)$. In experiment 2 , the enzyme was stored after precipitation with $\left(\mathrm{NH}_{4}\right)_{2} \mathrm{SO}_{4}(50 \%$ saturation) and redissolved in $0.05 \mathrm{~m}$ phosphate buffer $(p \mathrm{H} \mathrm{7.0)}$ for assay. The enzyme in both experiments was from step IV of Table 1 .

precipitated with ammonium sulfate, and a darkbrown fraction was obtained between 50 and $90 \%$ saturation. This fraction was dissolved in $50 \mathrm{ml}$ of water and dialyzed for $12 \mathrm{hr}$ against 6 liters of water. The dialyzed solution was applied to a second DEAE column ( 4 by $5 \mathrm{~cm}$ ) which was washed with $150-\mathrm{ml}$ portions of water and $0.05 \mathrm{M}$ and $0.1 \mathrm{M}$ potassium phosphate $(p \mathrm{H} 6.5)$; finally, the dark-brown protein was eluted with $0.25 \mathrm{M}$ potassium phosphate $(p \mathrm{H} \mathrm{6.5)}$. The protein was precipitated with ammonium sulfate $(90 \%$ saturation) and then dissolved in water. This brown protein $(5.9 \mathrm{mg} / \mathrm{ml})$ fraction was added to the above-described preparation of formate dehydrogenase, but it did not affect the rate of reduction of NADP. Addition of the brown protein to the more purified formate dehydrogenase also was without effect. The brown protein was then tested in the pyruvate clastic assay system from C. pasteurianum, and it did not stimulate production of acetyl-phosphate, whereas ferredoxins isolated from $C$. pasteurianum and $C$. thermosaccharolyticum were active. The $1 \mathrm{M}$ eluate obtained directly from the first DEAE column, and other fractions from $C$. thermoaceticum including crude extract, were also inactive in the ferredoxin assay. Therefore, we conclude that ferredoxin of the type found in $C$. pasteurianum does not exist in C. thermoaceticum.

Ferredoxins obtained from $C$. pasteurianum and from $C$. thermosaccharolyticum (20) had no effect on the formate dehydrogenase from $C$. thermoaceticum. Ferredoxin from $C$. thermosaccharolyticum was a gift from J. M. Akagi.
TABLE 3. Effect of oxygen on formate dehydrogenase from Clostridium thermoaceticum ${ }^{a}$

\begin{tabular}{|c|c|c|c|}
\hline $\begin{array}{l}\text { 2-Mercapto- } \\
\text { ethanol }\end{array}$ & Lag-period & $\mathrm{O}_{2}$ & $\begin{array}{l}\text { Rate of NADP } \\
\text { reduction }\end{array}$ \\
\hline umoles & $\min$ & $\mu \mathrm{mole} / \mathrm{ml}$ & $O D$ units $/ \mathrm{min}$ \\
\hline 0 & $<90$ & 0.083 & 0 \\
\hline 2.5 & 54 & 0.045 & 37 \\
\hline 4 & 38 & 0.011 & 47 \\
\hline 6 & 30 & 0.001 & 61 \\
\hline $6^{b}$ & 7 & & 59 \\
\hline
\end{tabular}

${ }^{a}$ Enzyme was purified by precipitation with ammonium sulfate ( $40 \%$ saturation) according to step I. The reaction mixture contained: formate, $20 \mu$ moles $/ \mathrm{ml}$; potassium phosphate buffer $(p \mathrm{H}$ 7.0), $50 \mu \mathrm{moles} / \mathrm{ml}$; NADP , $1 \mu \mathrm{mole} / \mathrm{ml}$; 2 -mercaptoethanol as indicated in the table; and $0.8 \mathrm{mg}$ of protein. The cuvettes were made anaerobic by flushing argon through a syringe needle inserted through the rubber stopper closing the cell. The lag period was measured from the time of addition of enzyme to the first indication of reduction of the NADP. Oxygen content of the reaction mixture was determined polarographically at $30 \mathrm{C}$ with a Clark Oxygen Electrode (Yellow Springs Instrument Co., Yellow Springs, Ohio) after the rate of reduction of NADP was linear. The samples were transferred from the cuvettes to the electrode chamber with a syringe to avoid contact with air. When no 2-mercaptoethanol was added, reaction did not occur and the $\mathrm{O}_{2}$ was determined after $90 \mathrm{~min}$. Incubations were at $50 \mathrm{C}$.

${ }^{b} \mathrm{~B}_{12}, 0.35 \mu \mathrm{mole}$, was added to the reaction mixture.

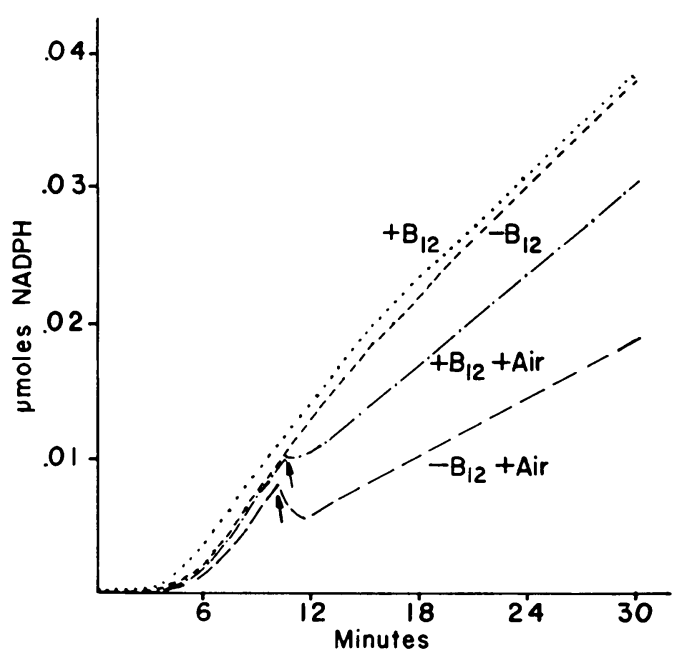

FIG. 7. Effect of oxygen and $B_{12}$ on formate dehydrogenase. Conditions as described in Fig. 2 with or without addition of $B_{12}$ as indicated; $0.169 \mathrm{mg}$ of purified enzyme; $0.1 \mathrm{ml}$ of air injected at arrow. 


\section{Discussion}

C. thermoaceticum ferments glucose under anaerobic conditions and, unlike a number of strict anaerobes, does not produce $\mathrm{H}_{2}$, but instead reduces $\mathrm{CO}_{2}$ to acetate. Formate is believed to be an intermediate in the formation of acetate. The question arises as to whether the NADPdependent formate dehydrogenase described here is responsible for this utilization of $\mathrm{CO}_{2}$. Although an exchange reaction between formate and $\mathrm{C}^{14} \mathrm{O}_{2}$ is catalyzed by the formate dehydrogenase, we were unable to demonstrate spectrophotometrically the oxidation of $\mathrm{NADPH}_{2}$ with $\mathrm{CO}_{2}$. This is not unexpected, since the oxidation-reduction potential for $\mathrm{NADPH}_{2}$-NADP is -0.324 and for formate- $\mathrm{CO}_{2}$ is $-\mathbf{0 . 4 4 0}$.

It is generally considered that reduction at this latter potential occurs via ferredoxin. Brill et al. (3) concluded that ferredoxin is involved in the oxidation of formate by extracts of $M$. omelianskii. Ferredoxin is also involved in the fermentation of pyruvate by several clostridia (17) as well as in its synthesis from acetyl-coenzyme $A$ and $\mathrm{CO}_{2}(1,15)$. Pyruvate seems to be involved in the total synthesis of acetate from $\mathrm{CO}_{2}(10)$, and it seems likely that pyruvate is a source of electron for this reduction of $\mathrm{CO}_{2}$ and that the reduction might occur via ferredoxin. Nevertheless, our results indicate that ferredoxin is not present in C. thermoaceticum, or if present differs from those of $C$. pasteurianum and $C$. thermosaccharolyticum. It is of interest that Smillie (16) isolated from a blue-green alga a flavoprotein with ferredoxin activity and that Knight and Hardy (Federation Proc. 25:413, 1966) isolated a similar compound (flavodoxin) from C. pasteurianum. Lan-Fun $\mathrm{Li}$ (unpublished data) isolated a protein probably containing flavin from $C$. thermoaceticum, having in its oxidized form absorption maxima at 275 , 360 (shoulder), 445, and 475 (shoulder) $\mathrm{m} \mu$. This protein when reduced with sodium hydrosulfide lost most of its absorption at 445 and $475 \mathrm{~m} \mu$. However, it did not stimulate the oxidation of formate by NADP, nor did it replace ferredoxin in the pyruvic clastic assay system from $C$. pasteurianum.

It is possible in $C$. thermoaceticum that the NADP-dependent formic dehydrogenase is responsible for the breakdown of formate to $\mathrm{CO}_{2}$ and that another electron carrier is involved in the synthesis of formate from $\mathrm{CO}_{2}$. Further studies are required to elucidate this problem.

The lag period observed in the reduction of NADP by formate appears to be caused by oxygen. This effect of oxygen is not a result of oxygen's replacing NADP as an acceptor of electrons, because the lag period was observed also in the isotope exchange with $\mathrm{C}^{14}$-formate (Fig. 1). If oxygen acted as an electron acceptor in preference of NADP, $\mathrm{C}^{14} \mathrm{O}_{2}$ would have been formed without a lag. The extreme sensitivity to oxygen and the high optimal temperature of formate dehydrogenase from $C$. thermoaceticum is in agreement with the optimal growth conditions for this bacterium. The oxygen sensitivity and the instability of the enzyme pose difficulties which must be overcome before more extensive purification is achieved.

\section{ACKNOWLEDGMENTS}

We thank C. Bernofsky for the determinations of oxygen.

This investigation was supported by Public Health Service grant GM 11839 from the Division of General Medical Sciences and by contract AT (-30-1)-1320 from the Atomic Energy Commission.

\section{LITERATURE CITED}

1. Bachofen, R., B. B. Buchanan, AND D. I. ARNON. 1964. Ferredoxin as a reductant in pyruvate synthesis by a bacterial extract. Proc. Natl. Acad. Sci. U.S. 51:690-694.

2. Barker, H. A., AND M. D. Kamen. 1945. Carbon dioxide utilization in the synthesis of acetic. acid by Clostridium thermoaceticum. Proc. Natl. Acad. Sci. U.S. 31:219-225.

3. Brill, W. J., E. A. Wolin, AND R. S. Wolfe. 1964. Anaerobic formate oxidation: a ferredoxin-dependent reaction. Science 144:297298.

4. Buchanan, B. B., W. Lovenberg, and J. C. RABINOWITZ. 1963. A comparison of clostridia ferredoxins. Proc. Natl. Acad. Sci. U.S. 49: 345-355.

5. Carnahan, J. E., and J. E. Castle. 1958. Some requirements of biological nitrogen fixation. $J$. Bacteriol. 75:121-124.

6. Colowick, S. P., N. O. Kaplan, and M. M. CIOTII. 1951. The reaction of pyridine nucleotide with cyanide and its analytical use. J. Biol. Chem. 191:447-459.

7. Gornall, A. G., C. J. Bardawill, AND M. M. DAVID. 1949. Determination of serum proteins by means of the biuret reaction. J. Biol. Chem. 177:751-766.

8. Hirs, C. H. W. 1955. Chromatography of enzymes on ion exchange resins, p. 113-125. In S. P. Colowick and N. O. Kaplan [ed.], Methods in enzymology, vol. 1. Academic Press, Inc., New York.

9. LENTZ, K., AND H. G. WoOD. 1955. Synthesis of acetate from formate and carbon dioxide by Clostridium thermoaceticum. J. Biol. Chem. 215:645-654.

10. Ljungdahl, L., E. IrION, AND H. G. WoOd. 1965. Total synthesis of acetate from $\mathrm{CO}_{2}$. I. Comethylcobyric acid and Co-(methyl)-5-methoxybenzimidazolylcobamide as intermediates with Clostridium thermoaceticum. Biochemistry 4:2771-2780. 
11. LuUngdahl, L., AND H. G. WoOD. 1965. Incorporation of $\mathrm{C}^{14}$ from carbon dioxide into sugar phosphates, carboxylic acids, and amino acids by Clostridium thermoaceticum. J. Bacteriol. 89:1055-1064.

12. Mortenson, L. E., R. C. Valentine, and J. E. Canahan. 1962. An electron transport factor from Clostridium pasteurianum Biochem. Biophys. Res. Commun. 7:448-452.

13. PeEL, J. L. 1963. The catalysis of the auto-oxidation of 2-mercaptoethanol and other thiols by vitamin $\mathbf{B}_{12}$ derivatives. Biochem. J. 88:296308.

14. PIRIE, N. W. 1946. The manometric determination of formic acid. Biochem. J. 40:100-102.

15. Raeburn, S., and J. C. Rabinowitz. 1965. Pyruvate synthesis by a partially purified enzyme from Clostridium acidi-urici. Biochem. Biophys. Res. Commun. 18:303-307.
16. SMillie, R. M. 1965. Isolation of two proteins with cloroplast ferredoxin activity from a bluegreen alga. Biochem. Biophys. Res. Commun. 20:621-629.

17. Valentine, R. C. 1964. Bacterial ferredoxin Bacteriol. Rev. 28:497-517.

18. Valentine, R. C., AND R. S. Wolfe. 1963. Role of ferredoxin in the metabolism of molecular hydrogen. J. Bacteriol. 85:1114-1120.

19. Warburg, O., and W. Christian. 1941. Isolierung and Kristallisation des Garungferments Enolase. Biochem. Z. 310:384-421.

20. Wilder, M., R. C. Valentine, and J. M. Akagi. 1963. Ferredoxin of Clostridium thermosaccharolyticum. J. Bacteriol. 86:861-865.

21. WooD, H. G. 1952. A study of carbon dioxide fixation by mass determination of the types of $C^{13}$-acetate. J. Biol. Chem. 194:905-931. 